\title{
IDENTIFYING THE SIGNIFICANCE OF HISTORIC PLACE IN SKOPJE'S OLD BAZAAR
}

- Based on analysis of facility's location and primary road in the Ottoman urban strategy -

\author{
スコピエ・オールドバザールにおける歴史的場所の意義 \\ -オスマン帝国の都市戦略にもとづく公共施設配置と主要道路の分析より-
}

\author{
Aleksandra KRSTIKJ ${ }^{*}$ and Hisako KOURA** \\ アレクサンドラクルスティック, 小浦久子
}

\begin{abstract}
Today the location and layout of public facilities and road network in the Bazaar, developed by the Ottoman urban strategy, have been losing their authentic purpose due to the modern development that ignored the Ottoman concept. The aim of this paper is to identify the original significance of places and recognize their meaning in the present urban structure of the Bazaar by analyzing the Ottoman concept in the layout and function of main public facilities and primary roads. The location significance was evaluated from three aspects: I) Main Center that represent the origin of the Ottoman city, II) Bazaar components or facilities that form the Bazaar's urban structure and III) periphery point of urbanization that give meaning to the Bazaar's location in the city's structure. The evaluation of location significance can serve as a base for rescuing the authentic Ottoman concept and managing future favorable development in the conservation of Skopje's Bazaar.
\end{abstract}

Keywords : Skopje’s Old Bazaar, Ottomanization, facility location, primary roads, significance of place スコピエ オールドバザール, オットマン化, 公共施設配置, 主要道路, 場所の意義

\section{Introduction}

Skopje's Old Bazaar, one of the biggest "complex weblike bazaars of medieval oriental character in the Balkans"1), is the only historic area that was proclaimed a Cultural Heritage of Significant Importance by the Macedonian Ministry of Culture (2008). Conservation and further careful planning of the Bazaar, developed during the Ottoman era of Skopje (1392-1912), is important to preserve the old city's identity and authenticity.

\subsection{Research aim}

Today the location and layout of public facilities and road network in the Bazaar, developed by the Ottoman urban strategy, have been losing their authentic purpose due to the modern development that ignored the Ottoman concept. Therefore, we examined the Ottoman concept in the layout and function of main public facilities and primary roads to identify their original significance and recognize the meaning of places in the present urban structure of the Bazaar. Careful consideration of the Ottoman concept and understanding of the authentic significance of locations can serve as guideline for future favorable development in the conservation of Skopje's Bazaar.

\subsection{Previous research and originality of our study}

Previous research of the Bazaar mainly concentrated on: historical facts regarding the construction of Ottoman public facilities and their architectural features (Sokoloski 197712), Богоевиќ-К. 19988)), the modern development in the Bazaar following Skopje's earthquake (Institute for Urbanism and Architecture-Skopje, 19673)) or the typology of shops (Krstikj, Hyuga, Koura 201213)). The study by Boykov (2011)9) clarifies the consistent Ottoman urban strategy-Ottomanization, applied in the conquered Balkan cities, including Skopje, during $15^{\text {th }}$ century. Concurrently, Mateska's study (2011)1) analyzes the typology and function of all traditional Bazaars in the structure of Macedonian cities without focusing in particular on Skopje's Bazaar.

In 2006, the N.I. - Conservation Center Skopje executed a Reevaluation survey of Skopje's Bazaar ${ }^{14)}$ that served as a base for enacting the Law for Protection of the Bazaar (2008). Although the Reevaluation Report presents large quantity of historical facts and survey records regarding the surviving monuments, it lacks a consistent explanation of the meaning of place in the Bazaar's urban structure. Therefore, our study focuses on clarifying the significance of place in the particular case of Skopje's Bazaar, based on the authentic function of facility's location and primary road.

\subsection{Methodology}

The method of this study was based on document analysis. The documents consisted of previous research and historical data. Previous research was analyzed to establish the Ottoman urban

\footnotetext{
* Doctoral Candidate, Graduate School of Engineering, Osaka Univ., M. Eng. ** Assoc. Prof., Graduate School of Engineering, Osaka Univ., Dr. Eng.
}

大阪大学大学院工学研究科 大学院生 $\cdot$ 博士後期課程 大阪大学大学院工学研究科 准教授 ·博士 (工学) 


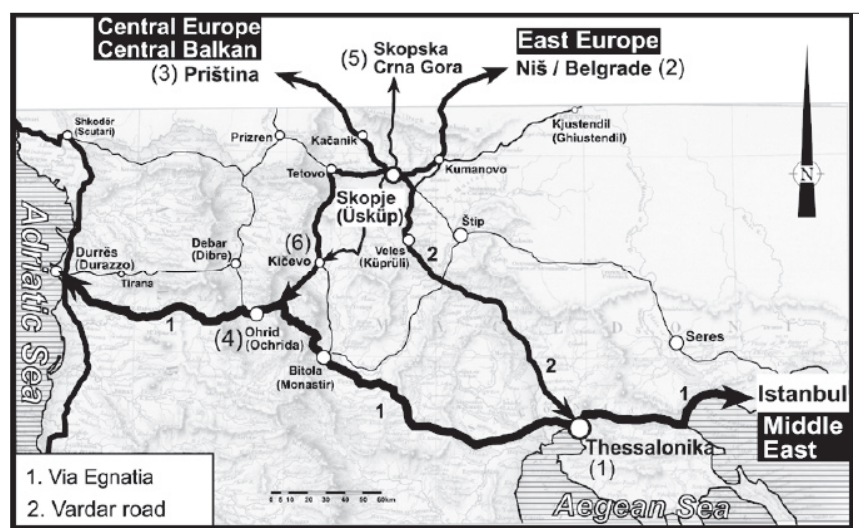

(1) Skopje-Veles-Thessaloniki (Aegean S.) - Istanbul-Middle East

(2) Skopje-Kumanovo-NišBelgrade-East Europe

(3) Skopje-Kačanik-PrištinaCentral Balkan-Central Europe

(4) Skopje-Tetovo-KičevoOhrid-Durrës (Adriatic Sea)

(5) Skopje-villages in Skopska Crna Gora Mountain

(6) Skopje-villages in Vodno Mountain (Nerezi) - Kičevo

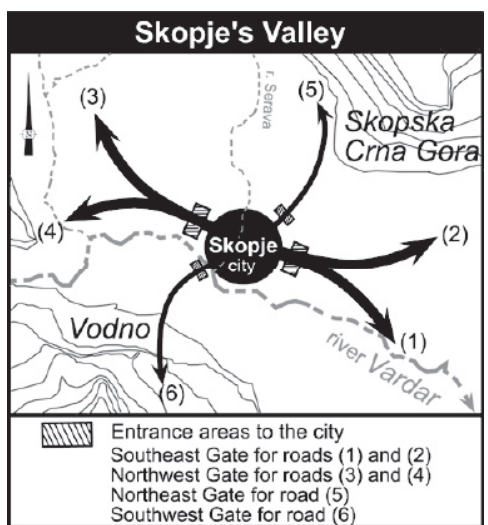

Fig.2 Skopje's valley (based on Evans 1883 strategy (Cezar 198310), Boykov 20119)), year of built and location of facilities (Sokoloski 197712), Богоевиќ-К. 19988)), social circumstances (Gorgiev 199711)) and urban planning of the Bazaar after the 1963 earthquake (Institute for Urbanism and Architecture-Skopje, 19673)). From the historical data we used maps by Hall5) (1828) and Evans6) (1883) of the Skopje's region, a map of Skopje from 1887/95 and photographs of Skopje from the early $20^{\text {th }}$ century (Archive of Macedonia). The 1887/95 map was found in an article by Urošević published by the Macedonian Academy of Science and Arts's "Contributions IV-2", 19732). Urošević on the other hand, found the 1887/95 map as appendix in a book titled "Detailbeschreibung des Sandžaks Plevlje und des Vilajets Kosovo"printed in Vienna 1899²).

\section{Skopje's location on the regional transit network}

Skopje's valley had been inhabited since ancient times ${ }^{3)}$. In the Roman Empire, main highways were connecting Rome with Constantinople. One of the most important roads Via Egnatia passed through the southern parts of today Republic of Macedonia (Ohrid-Bitola) ${ }^{4}$. In this context Skopje's valley had a periphery position. However, the situation drastically changed after 1392 when Skopje was conquered and renamed Üsküb by the Ottomans ${ }^{4}$. Since then, Skopje served an important military and political role as a base for further conquests of the North and Central Balkan4). These new circumstances gave strategic significance to Skopje and its location in the region ${ }^{1}$.

On the map from Hall (1828)5) we traced the regional transit network passing through Skopje, already firmly established in the $19^{\text {th }}$ century (Fig. 1). It became clear that Skopje was a traffic link between Central/East Europe and Thessalonica on the Aegean Sea, from where the Middle East was accessed. The road Skopje-Thessalonica was along Vardar's riverbed. Another route of more local importance connected Skopje as urban center with its hinterland, the villages in Skopska Crna Gora (northeast) and Vodno Mountain (southwest). This route was in SW-NE direction and its vital link was the Stone Bridge on river Vardar. We can clarify the main significance of Skopje's location in being important intersection on the regional network between Central/East Europe and the Middle East and urban center for the local villages.

\subsection{Skopje's valley}

Skopje city is located in Skopje's valley which is elongated river plain in the northern part of today's Republic of Macedonia. Enclosed by mountain Vodno (1066m) on the south, Suva Gora $(1857 \mathrm{~m})$ on the southwest and Skopska Crna Gora $(1561 \mathrm{~m})$ on the northeast ${ }^{3)}$, the valley is naturally accessed in the NorthwestSoutheast direction which is along the flow of river Vardar. On Fig. 2 we traced the direction of the regional network through Ottoman Skopje based on the map from Evans (1883)6). It became clear that the main NW-SE regional highway passed through the city along the Vardar riverbed. We mapped the entrances of the regional roads in the city zone which are called hereafter Gates.

\section{Purpose of facility's location in Ottoman urban strategy}

In this chapter we discuss the purpose of facility's location in the Ottoman urban strategy in order to recognize the authentic significance of public facility's place in Skopje's urban structure.

\subsection{Urban structure of Ottoman Skopje}

After the Ottomans conquered Skopje in 1392, the city was gradually restructured according to the basic principles and guidelines of the Ottoman urban concept that derived from the Islamic religious law-Sharia ${ }^{10)}$. In conformity with these basic principles, Ottoman Skopje had three main urban zones: urban center with the Main Mosque and the Bazaar, a Fortress adjacent to the Bazaar and residential neighborhoods surrounding the urban center $^{1)}$. The residential neighborhoods (mahalle) were settled by people from the same ethnicity and each had a small center with praying place, a bakery and a public bath ${ }^{1)}$. In the mahalle, the privacy of family life was respected while the commercial activities as provision of food, import of raw materials and trade culminated in the noisy streets of the Bazaar ${ }^{4}$. We mapped the location of the Bazaar and adjacent Fortress on the 1887/95 map (Fig. 3).

The urbanized area on the $1887 / 95$ map is $\sim 260$ hectares with only small area ( $\sim 5$ hectares) on the right bank of river Vardar, mostly as a result of the first railway station built in $1874^{2}$. Observing the topographical markings, it became obvious that 
Skopje was developed between two relief folds, the Fortress Hill on the west and Gazi Baba Hill on the east, with river Serava flowing in between. The geography of the terrain made the Fortress Hill a perfect defense point, unapproachable from the southwest steep side and gently opening to the eastern valley. Previous research suggests that the east border of early medieval Skopje was river Serava ${ }^{3)}$ however, in 1887/95 the city already spread on the northeast engulfing the Serava canal in the middle of the city. The allocation of public facilities determined the Bazaar's elongated shape in SW-NE direction with the Fortress (west), r. Vardar (south) and r. Serava (east) as its boundaries.

\subsection{Skopje's Ottomanization process}

The Ottomans used an urban strategy for reshaping their conquered cities-Ottomanization ${ }^{9}$. The strategy consisted of: 1 . placing a Main communal Friday Mosque in the center of the city, with purpose of developing a commercial zone-Bazaar in that area and 2. placing $\mathrm{T}$-shaped community centers-complexes consisting of Mosque, public kitchen, religious school, hospital and other facilities in the outskirts of the city with a purpose of facilitating urban growth of new residential neighborhoods ${ }^{9}$.

In Skopje, the Ottomanization started in the $15^{\text {th }}$ century. The Main communal Mosque built in Skopje's urban center was identified by Boykov as the first mosque built by the conqueror Paşa Yiğit Bey (Fig. 3, A) in 14149). In the Bazaar that started to develop around the Main Mosque, Paşa Yiğit's successor Ishak Bey built the Bedesten (Fig. 3, B) in 1439, as a hub of all commercial activities ${ }^{8,9)}$. Therefore, these two public facilities signify the origin of the Ottoman city and hereafter we refer to them as Main Centers of Ottoman Skopje.

Boykov identified the first two complexes built on the city's outskirts in Ishak Bey (C, y.1439) and Gazi Isa Bey Mosque (E, y.1475) locations ${ }^{10)}$. Sultan Murat II built a mosque (D, y.1438) that included a complex of other facilities, on a small hill overlooking the Bazaar that officially recognized Skopje as important Ottoman city $^{8}$. The intensive building activities in the $15^{\text {th }}$ century coincide with the growth of number of inhabitants. D. Gorgiev's research (1998) on the demographical changes in Skopje after the Ottoman conquest ${ }^{11}$, based on the Census books Tapu defterleri, was used to prepare a table showing the number of neighborhoods, households and inhabitants in Skopje in 1452/3, 1467/8, 1544 and 1568/9 (Table 1/I,II,III,IV). However, Gorgiev informs that the number of households is not exact but fairly accurate because of the Ottoman practice not to include citizens with special status and the ruling feudal families in the Census books ${ }^{11)}$. From the table we can discern the steady growth of Skopje's population from 1452 to 1544, which supports Boykov's claim that location of C, E and D complexes were aimed at facilitating Skopje's growth and hereafter we will refer to them as First period complexes. Since the population again rose rapidly from 1544 to 1568 , we can confirm that the city growth
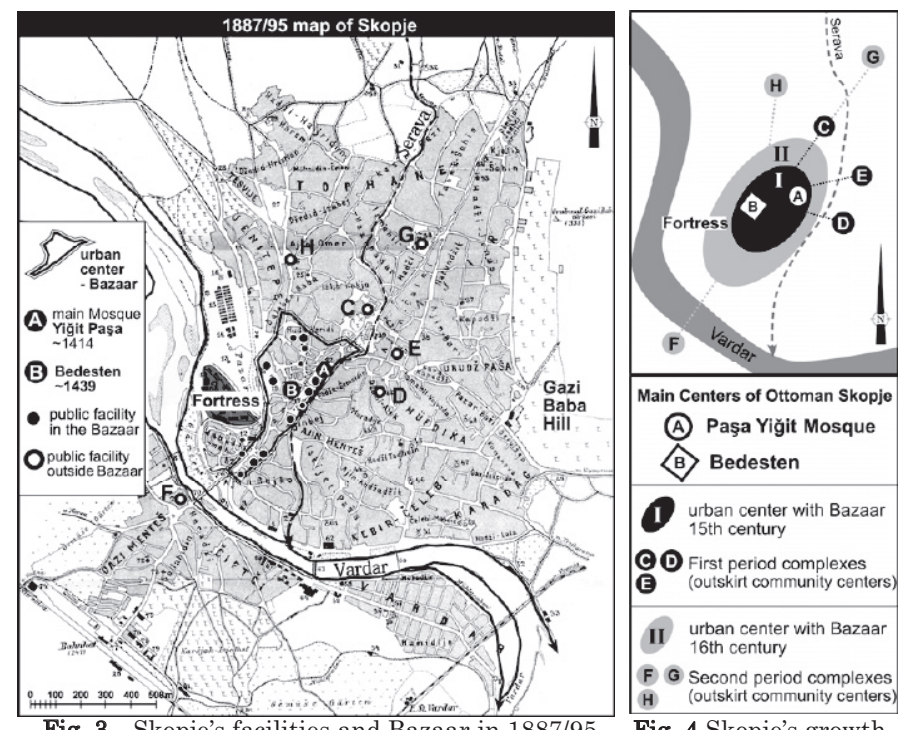

Fig. 3 Skopje's facilities and Bazaar in 1887/95 Fig. 4 Skopje's growth

\begin{tabular}{|c|c|c|c|c|c|c|}
\hline & I & ॥ & III & IV & $\mathrm{v}$ & VI \\
\hline & y. $1452 / 3$ & y. $1467 / 8$ & y. 1544 & $y .1568 / 9$ & 1660 & y. 1875 \\
\hline Christian neighborhoods & 8 & 12 & 14 & 10 & - & $=$ \\
\hline neighborhoods in total & 31 & 45 & 67 & 67 & $\overline{70(?)}$ & $\overline{51^{*}}$ \\
\hline Christian households & 339 & 363 & 224 & 547 & 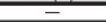 & 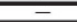 \\
\hline Muslim households & 516 & 666 & 1,067 & 1,485 & $=$ & $=$ \\
\hline $\begin{array}{l}\text { Jewesh households } \\
\text { Chatolichousehalds }\end{array}$ & - & - & $\frac{32}{8}$ & $\frac{53}{30}$ & $\overline{-}$ & $=$ \\
\hline number of inhabitants & $\sim 4,275$ & $\sim 5,145$ & $\sim 6,655$ & $\sim 10,575$ & $\sim 60,000(?)$ & $\sim 29,480$ \\
\hline
\end{tabular}

started with the Ottomanization in the $15^{\text {th }}$ century continued and intensified during the $16^{\text {th }}$ century. Important facilities that were located outside the Bazaar area in early $16^{\text {th }}$ century were: Burmali (F, y.1495), Yaya Paşa (G, y.1504) and Dükkânçik (H, y.1549) Mosque. We concluded that these outskirt communal facilities most probably had the meaning of Second period complexes after the First period complexes were engulfed in the new neighborhoods (Fig. 4). The purpose of the Second period complexes was probably the same: to facilitate further urban development. This is supported by several historic records that describe Skopje in 1660 as a big city with 60000 inhabitants (Table 1/V)11) (Gorgiev warns that these records are probably exaggerated. However, they affirm the city's rapid growth from mid $16^{\text {th }}$ to $\mathrm{mid} 17^{\text {th }}$ century).

Skopje's growth was abruptly stopped by the 1689 fire set by the retreating Austrian army in the Great Turkish War (1683-1699) which caused great damages and reduced significantly the urban structure and population ${ }^{1), 11)}$. The city gradually recovered and according to the inscriptions on the $1887 / 95$ map by the end of the $19^{\text {th }}$ century Skopje had around 51 neighborhoods including the first orthogonal planned neighborhood on the right bank of Vardar.

\section{Purpose of primary road in Ottoman urban strategy}

According to Hakim (1988) ${ }^{7}$, in traditional Arabic-Islamic cities the road network is composed of: primary, secondary and tertiary roads ${ }^{7}$. The purpose of primary road is the continuation of the regional highway that enters through the city Gate and forms the backbone of the city. All major public facilities are located along the primary roads and the final destinations are the Main Mosque, the Bedesten and the Fortress ${ }^{7}$. 
In our analysis the term "primary road" is used in the context defined by Hakim for Skopje's road network in 1887/95 map. Urošević (1973) discussed the 1887/95 map with interest in its content and exact period of production ${ }^{2}$. We used the map to identify the primary roads of Skopje that were utilized to connect the regional transit network and the main public facilities in the Ottoman urban strategy. We focused on identifying roads that connected the City gates of the regional network to open markets for wholesale, Main Mosque, Bedesten and the Fortress.

4.1.City gates, open wholesale markets and main public facilities

First we identified the precise location of Skopje's City Gates (Fig. 5). We use the term City Gates for the naturally formed entrances to the city area. These entrances provide access for the regional network in the city. The topography of the terrain allows open entrance to the city only from the northern plain while the traffic from the other three sides is forced through natural passages. The passage formed by the northwest slope of the Fortress Hill and the hill adjacent to it on the north side is named in this study NW Gate. Historically, this place was called Tetovska Trošarina meaning Toll Gate for traders coming from Tetovo city on the west (4). The Stone Bridge, as the only entrance over river Vardar, was named SW Gate. The strategic positioning of the Fortress Wall and the direction of its defensive posts and towers suggest a clear intention of guarding the Bridge as important city entrance. The southeast passage to the old city between the Gazi Baba Hill and river Vardar is wider. For its precise location we used a historical name of a place below the Hill called Kumanovska Trošarina meaning Toll Gate for traders coming from Kumanovo city (2). On the northeast, a Gate was not marked but the contour of the city itself is considered a NE Gate. We assume that in early Ottoman time a NE Gate could have been a passage over river Serava as natural border.

Secondly we marked the location of two big Open Markets in the city: one in front of the Fortress Gate-OM1 (Photo 5) and another-OM2 (Photo 3) on the plain between Ishak (C) and Gazi Isa Bey (E) Mosques. From previous research we know that these were the two biggest Open Markets in Ottoman Skopje ${ }^{1}$.

Thirdly we marked the location of the Main Centers- Paşa Yiğit Mosque and Bedesten as arrival points of primary significance for the city. The First and Second period outskirt complexes were also considered vital traversal locations. (Fig. 5)

\subsection{Primary roads on the $1887 / 95$ map}

To identify which roads had a meaning of primary, we searched for roads that connect the location of the city Gates, open markets and the main Ottoman public facilities (Fig. 5). From the Stone Bridge (SW Gate) where Burmali Mosque (F) is located, a road continues to the locations of Bedesten (B), Paşa Yiğit (A), Ishak Bey (C) and Yaya Paşa (G) Mosques and provides exit to the villages in Skopska Crna Gora. This road in SW-NE direction was identified as primary road $\boldsymbol{A B C}$. From the NW

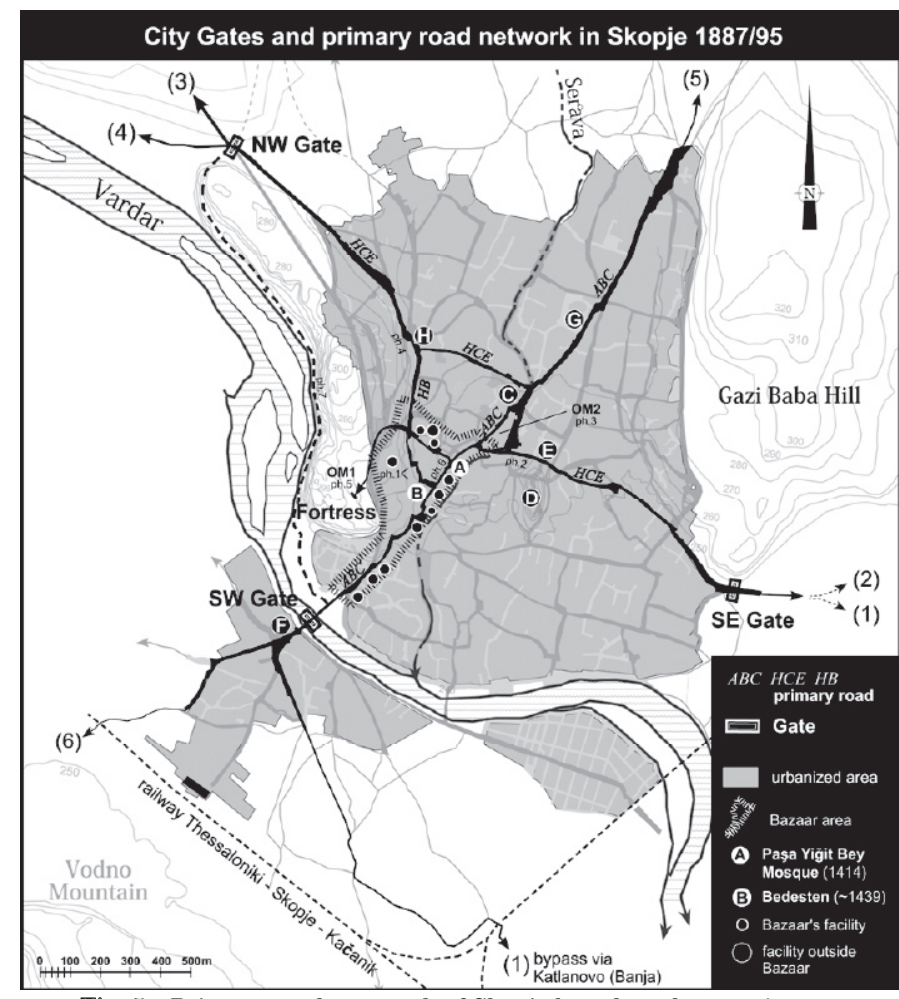

Fig. 5 Primary roads network of Skopje based on the 1887/95 map

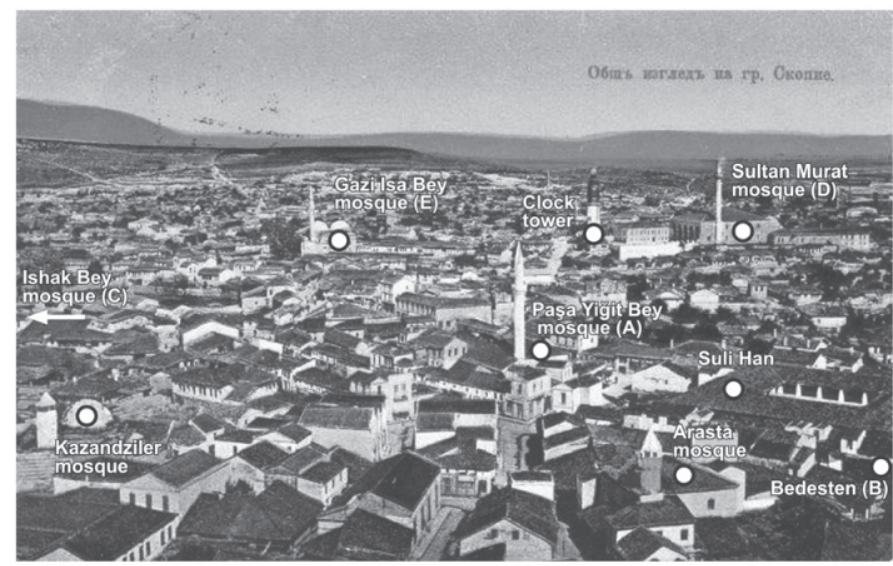

Photo 1 View from the Fortress Hill towards the Bazaar

The photo was taken from "N.I. Conservation Center Skopje" database

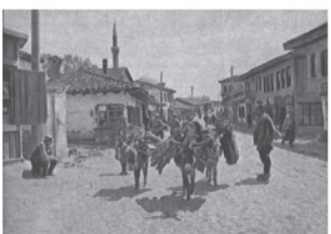

Photo 2 Road to SE Gate

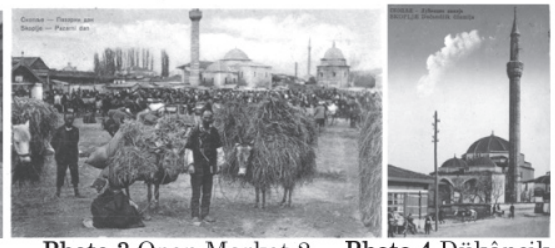

Photo 3 Open Market 2 Photo 4 Dükânçik
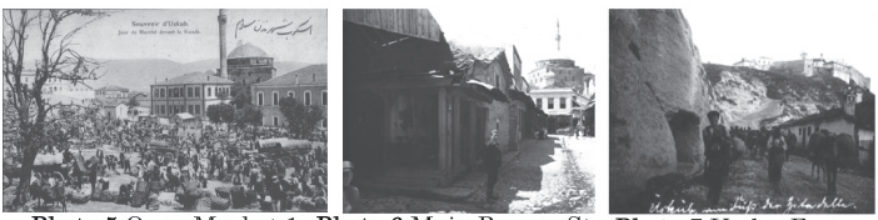

Photo 5 Open Market 1 Photo 6 Main Bazaar St. Photo 7 Under Fortress

Gate, a road continues to Dükkânçik (H), Ishak Bey (C) and Isa Bey

(E) Mosques and exits at the SE Gate. This road bypasses the Bazaar and the urban center from the north. It was named primary road $\boldsymbol{H C E}$. $\mathrm{ABC}$ and $\mathrm{HCE}$ primary roads intersect at the $\mathrm{C}$ (Ishak Bey Mosque) where OM2 is located. We identified a south branch of 


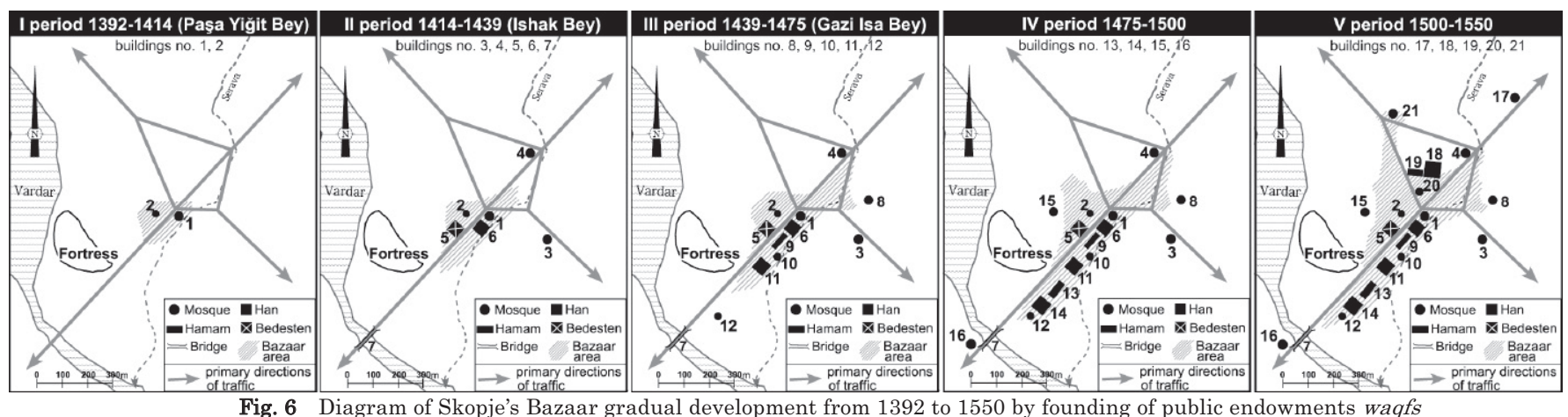

Fig. 6 Diagram of Skopje's Bazaar gradual development from 1392 to 1550 by founding of public endowments waqfs

the $H C E$ primary road that starts at Dükkânçik Mosque (H) and provides direct entrance to the Bedesten (B) Main Center. This road was named primary road $H B$. From $H B$ an access to the Fortress (west) and the Main Mosque Paşa Yiğit (A-east) is also provided. Therefore, we identified the primary road network of Ottoman Skopje that functioned as link between the regional network and the main public facilities. To support this analysis, we used photos taken near main public facilities from end of $19^{\text {th }}$ and beginning of $20^{\text {th }}$ century. The photos are old postcards found in the Archives of Macedonia. All photographs show wide streets lined with shops and bustling open markets that confirm the frequent use of roads near the main public facilities. Photo 6 was taken 1913 on the ABC primary road between the Main Centers Bedesten and Paşa Yiğit Mosque. Along this road majority of Bazaar's facilities are placed thus, this road had a meaning of Main Bazaar Street. Today it's named Pokriena Čaršija.

\section{Facility's location and primary road in Bazaar's development}

The aim of this discussion is to identify the authentic function of public facility's location and primary road in the development of the Bazaar area.

\subsection{The Ottoman traditional construction system}

Skopje's Bazaar was formed by the traditional Ottoman construction system that is based on a Muslim concept of waqf endowments realized by powerful Ottoman individuals or officials ${ }^{10)}$. The endowment-waqf is a property that is "frozen", exempt from changes and subdivision for centuries, and dedicated to serve public benefit ${ }^{11}$. These public facilities were permanent or static element in the urban fabric and often not single buildings but groups or complexes of buildings that functioned as social welfare centers ${ }^{10}$. The founder allocated other property for financial support of the facility in a case of a building that did not yield income (Mosque, school, public kitchen ext. (11), 12). Public facilities like Han, Hamam or Bedesten that yielded income supported themselves and even some of the other public facilities ${ }^{13)}$. Soon after a public facility was founded in the Bazaar, around its walls small shops were spontaneously generated often using the facility's facade as their rear wall ${ }^{10}$. These shops on the other hand were subject to dynamic changes, rebuilding and subdivision to adjust to the needs of the owners ${ }^{13}$.

\subsection{Gradual growth of the Bazaar area from 1392 to 1550}

From 1392 to 1414 , the center of the city and the location of the Bazaar were determined by the construction of the first Mosque Paşa Yiğit9). Near Paşa Yiğit Mosque, Arasta Mosque was built ("arasta" - street or row of shops whose income is allocated to waqf support ${ }^{10)}$, Fig. 6/I). To boost up the commercial and social activities, powerful individuals gradually erected other public facilities that served as communal or trading centers ${ }^{1), 8)}$. Paşa Yiğit's successor Ishak Bey (1414-1439) built the most important commercial building in the Bazaar — the Bedesten building, as well as a big Han on river Serava named Suli Han (su-water, Fig. 6/II). Isa Bey (1439-1475) on the other hand constructed the Kapan Han and Çifte Hamam ${ }^{1), 8}$ (Fig. 6/III). Until 1550, a large number of public facilities were already established (Fig. 6/IV,V) and the Bazaar was well developed thus, the waqf construction significantly slowed down ${ }^{1,8)}$. Therefore, we can conclude that the main urban structure of the Bazaar was developed in the first 150 years of the Ottoman rule in Skopje. It consisted of two Main Centers (Paşa Yiğit Mosque and Bedesten) as the origin of the Ottoman Skopje's urban center and other facilities located mainly along the Main Bazaar Streetpart of the SW-NE Ottoman primary road (road ABC on Fig. 5).

\section{Physical change of Bazaar's structure by modern development}

During the $20^{\text {th }}$ century, the Balkan Wars and two World Wars, as well as the earthquake of 1963, severely damaged the historic buildings ${ }^{1), 15)}$. Moreover, Skopje's Urban Plan of 1964 and the Reconstruction project of the Bazaar by the Institute for Urbanism and Architecture-Skopje (1967-70) ${ }^{3)}$ brought about destruction to the spatial context of the Ottoman urban concept. Following are major developments that damaged Bazaar's urban structure (Fig. 7) 1. Museum of Macedonia was constructed on the primary road that connects the Bazaar to Dükkânçik Mosque and NW Gate (road HB on Fig. 5). Thus the primary road network was cut off and the entrance to the Center, where Bedesten is located, was obscured.

2. A major auto road was constructed across the south area of the Bazaar. This road cut off the SW-NE primary road (ABC on Fig. 5) that leads to the Stone Bridge (7) from the Main Bazaar Street. The south area of the Bazaar, where Daut Paşa Hamam (13) is located, is now physically separated from the rest of the Bazaar.

3. Relocating of river Serava in 1968 promoted redevelopment at 


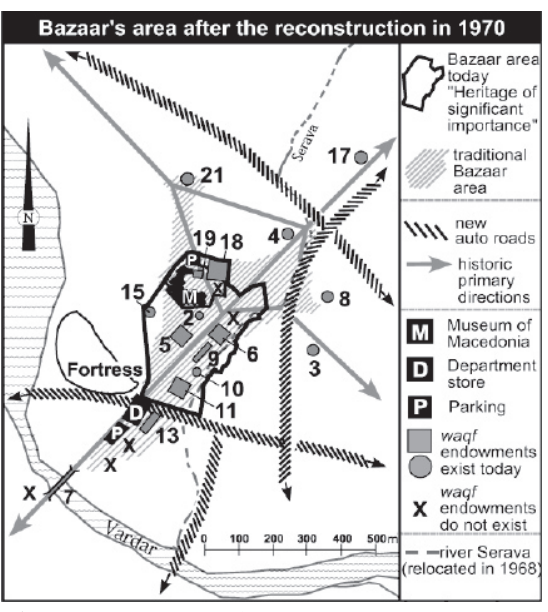

Fig. 7 Bazaar area after 1967-70 reconstruction
Table 2 Main Ottoman public facilities built from 1392 to 1550 and evaluation of facility location

\begin{tabular}{|c|c|c|c|c|c|c|c|}
\hline & built year & exist today & orig. location & location now & kept orig. function & authenticity* & value $^{\star \star *}$ \\
\hline 1. Paşa Yiğit Bey Mosque & 1414 & $\bar{x}$ & $\mathbf{E}$ & $\mathbf{E}$ & 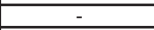 & & $\mathrm{I}$ \\
\hline 2. Arasta Mosque & $\sim 1414$ & 은 & $\overline{\mathbf{E}}$ & $\overline{\mathbf{E}}$ & - & $\triangle \mathrm{RO} ; \mathrm{RR}$ & II \\
\hline 3. Sultan Murad II Mosque & 1436 & 은 & $\bar{\square}$ & $\bar{\square}$ & 은 & $\triangle \mathrm{RO} ; \mathrm{RE}$ & III \\
\hline 4. Ishak Bey Mosque & $\sim 1439$ & 으 & $\bar{\square}$ & $\bar{\square}$ & - & $\mathbf{A}$ & III \\
\hline 5. Bedesten & $\sim 1439$ & 0 & $\underline{\square}$ & 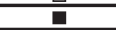 & $\bar{X}$ (mixed use) & $\Delta \mathrm{RO} ; \mathrm{RE}$ & $\frac{1}{1}$ \\
\hline 6. Suli Han & $\sim 1439$ & $\overline{0}$ & $\overline{\mathbf{E}}$ & $\bar{\square}$ & $\mathrm{X}$ (culture) & $\triangle \mathrm{RO} ; \mathrm{RE}$ & II \\
\hline 7. Stone Bridge & $1421-1451$ & Q & $\bar{\square}$ & $\bar{\square}$ & 0 & $\Delta$ & III \\
\hline 8. Gazi Isa Bey Mosque & $\sim 1475$ & 으 & 믄 & 믄 & 으 & $\Delta$ & III \\
\hline 9. Cifte Hamam & $\sim 1475$ & - & $\overline{\mathbf{E}}$ & $\mathbf{\square}$ & $\mathrm{X}$ (culture) & $\Delta \mathrm{RR}$ & II \\
\hline 10. Murat Pașa Mosque & $\sim 1475$ & 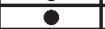 & $\overline{\mathbf{n}}$ & $\overline{\mathbf{n}}$ & 0 & $\Delta \mathrm{RO} ; \mathrm{RR}$ & II \\
\hline 11. Kapan Han & $\sim 1475$ & 은 & $\overline{\mathbf{E}}$ & $\bar{\square}$ & $X$ (mixed use) & $\Delta$ RORE & II \\
\hline 12. Ibn Payko Mosque & $\sim 1475$ & $\bar{x}$ & 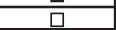 & 만 & 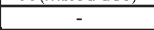 & & II \\
\hline 13. Daut Paşa Hamam & late 15th c. & 으 & $\bar{\square}$ & प & $X$ (culture) & $\mathbf{A}$ & II \\
\hline 14. Daut Paşa Han & late 15th $c$. & $\bar{x}$ & $\bar{\square}$ & $\square$ & - & & II \\
\hline 15. Mustafa Pașa Mosque & 1492 & - & $\overline{\mathbf{E}}$ & $\overline{\mathbf{E}}$ & 0 & $\mathbf{A}$ & II \\
\hline 16. Burmali Mosque & 1495 & $\bar{x}$ & $\bar{\square}$ & $\bar{\square}$ & & & III \\
\hline 17. Yaya Paşa Mosque & 1504 & $\overline{0}$ & 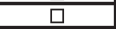 & 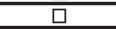 & - & $\Delta$ & III \\
\hline 18. Kurşumli Han & $\sim 1549$ & Q & $\overline{\mathbf{E}}$ & $\overline{\mathbf{E}}$ & $\overline{X \text { (culture) }}$ & $\Delta \mathrm{RE}$ & II \\
\hline 19. Ģurçiler Hamam & $\sim 1549$ & $\bar{R}$ & $\overline{\mathbf{E}}$ & $\bar{\square}$ & - & $-(R)$ & II \\
\hline 20. Kazançiler Mosque & $\sim 1549$ & $\bar{x}$ & $\overline{\mathbf{E}}$ & $\overline{\mathbf{E}}$ & - & $E$ & II \\
\hline 21. Dükkânçik Mosque & $\sim 1549$ & 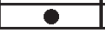 & $\bar{\square}$ & $\bar{\square}$ & 은 & $\Delta \mathrm{RR}$ & III \\
\hline
\end{tabular}

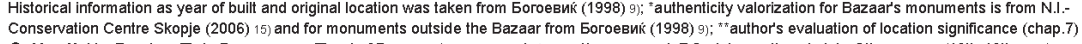

- Yes: X-No: R- ruins: - in Bazaar area: $\square$-out of Bazaer: $\mathbf{A}$ - preserved: $\Delta$ - partly preserved: RO- interventions in late Ottoman era (18th-19th cen the periphery of the Bazaar and resulted in loss of recognition for the authentic edge as well as the waterfront character.

Even though the Reconstruction Project altered the authentic urban structure of the Bazaar, the location and layout of facilities and primary roads still carry the meaning of place developed by the Ottoman urban strategy. For example, the significance of the Bedesten location as Main Center is still preserved although the authentic building is lost and the entry from the north side is obscured. The Stone Bridge still have the significance of South Gate to the Bazaar. The original significance of location of public facility and primary road can be recognized by careful examination of the Ottoman urban strategy in the present layout of the Bazaar.

\section{Conclusion}

According to the previous examination of Ottoman urban strategy, public facilities and roads in the present Bazaar preserve the significance of their location and layout by the Ottoman concept. Although in some places the original buildings were lost, the location possibly preserves the significance of the Ottoman concept. The location significance was evaluated from three aspects: I) Main Center, II) Bazaar components and III) periphery point of urbanization.

I) Pasa Yiğit Mosque and the Bedesten signify the Main Center that is the origin of the Ottoman city. Although the original buildings were lost, preservation of the location concept of Bedesten and Pasa Yiğit Mosque, in terms of place making, is crucial for recognizing the center of the historic city. (Table 2)

II) Ottoman facilities in the Bazaar carry the Ottoman concept that formed the Bazaar as an urban center. Even though some of them have been altered due to repairs and rebuilding, their layout and original functions are significant to understand the Ottoman urban structure of the Bazaar. (Table 2)

III) First and Second period outskirt complexes signify the periphery of Ottoman urbanization. Their visibility from the Bazaar's area provides orientation and thus the location of the Bazaar in Ottoman Skopje is understood. (Table 2)
The primary road network signifies a link between the regional network and Ottoman Skopje. Preservation of the primary roads is vital for providing meaning to the location of the historic city in the region and the location of the Bazaar and its facilities in the city. In the Bazaar, the most significant road is Pokriena Čaršija along which most of Bazaar's facilities are oriented.

The evaluation of location significance can serve as a base for rescuing the authentic Ottoman concept and managing future favorable development in the conservation of Skopje's Bazaar.

\section{References}

1) Mateska., G. S.: Bazaar in the Architectural and Urban structure of Towns in the Republic of Macedonia, Cultural and Historic Heritage of R. Macedonia LVII ed., N.I.-Conservation Centre Skopje, 2011 (Macedonian)

2) Urošević, A.: Le Plan de Skopjé de la fin du XIX siécle, Maced. Academy of Science and Arts (Social Sciences), Vol. IV/2, pp.23-30, Skopje 1973 (Mac.)

3) Стара чаршија, Institute for Urbanism and Arch.-Skopje, 1967 (Mac.)

4) Castellan, G.: History of the Balkans from the Mohammed the

Conqueror to Stalin, Columbian University Press, New York, p. 132, 1992 5) David Rumsey Map Collection, http://www.davidrumsey.com, 07.04.2012

[ Hall, S. (Sidney): Greece, published by Longman, Rees, Orme, Brown \& Green, Paternoster Row, London, Janyary 1st. 1828]

6) Evans, A.J.: Antiquarian Researches in Illyricum, Part III and IV, Nichols and Sons, Westminster, pp. 82-152, 1883

7) Hakim, S.B.: Arabic-Islamic Cities-building and planning principles, Kegan Paul International, London, 1988

8)Богоевиќ-К.,Л.: Османлиски споменици во Скопје, Исламска заедница во РМ-Скопје, Сектор за наука и исламска култура, 1998 (Macedonian)

9) Boykov, G.: Reshaping urban space in the Ottoman Balkans: a study on the architectural development of Edirne, Plovdiv and Skopje (14-15cen.), Centers and Peripheries in Ottoman Architecture: Rediscovering Balkan Heritage, Max. Hartmuth ed., pp. 32-45, Sarajevo, 2011

10) Cezar, M.: Typical Commercial Buildings of the Ottoman Classical Period and the Ottoman Construction System, Türkiye Iş Bankasi Cultural Publications, Istanbul, 1983

11) Gorgiev, D.: Skopje from the Turkish Conquest till the end of XVII century, Macedonian Institute of National History, pp. 37-59, Skopje, 1997 (Mac.)

12) Sokoloski, M.: Les Biens des vaqyf a Skopje et dans la region environnante au $X V^{e}$ et $X V I^{e}$ siecle, Contributions of the Macedonian Academy of Science and Arts, Vol. 8/2, pp. 27-82, Skopje, 1977 (Mac.)

13) Krstikj, A., Hyuga, S., Koura, H.: Study on typology of shops and their transformations in Skopje's Old Bazaar-based on analysis of vernacular units'form and design elements, J. Archit. Plann., AIJ, Vol. 77 No. 678, pp 1881-1887, 2012.8

14) Revalorization Report of Old Skopje's Bazaar, Skopje: National Institution Conservation Centre-Skopje, 2006 (in Macedonian) 


\section{和文要約}

オスマンの計画コンセプトを軽視した近代の開発によって、現在 では、オスマンの都市戦略にもとづき開発されたバザールを構成す る公共施設の立地や道の配置における本来の目的や意味が見失われ つつある。本研究では、これら公共施設と主要道路の配置や機能に おけるオスマンの計画コンセプトを調査分析することにより場所の 本質的重要性を確認し、現在のバザールの都市構造においてその意 味を認識することを目的とする。分析の結果、現在のバザールにお ける場所の重要性は 3 つの観点から評価することができる：1)オス マン都市の起源を示すメインセンターとしての価值、2) バザールの 都市構造を形成してきた施設や構成要素としての価值、3)都市のな かでのバザールの位置を確認するうえで都市の周縁を示す要素とし ての価值。これら場所の重要性の評価はオスマンの計画コンセプト を再生させる拠り所とすることができ、また、今後のスコピエ・バ ザールの保全において、望ましい開発管理を求めていく基本となる。

(2012年 7 月 10 日原稿受理, 2013 年 1 月11日採用決定) 